\title{
Stakeholder behavior and legislative influence: A case study of recreational water rights in Colorado
}

\author{
Deserai Anderson Crow* \\ School of Journalism and Mass Communication, University of Colorado, Boulder, Boulder, CO 80309, USA
}

\begin{abstract}
Colorado water law is based on 150 years of legal, constitutional, and administrative precedent. Much of this precedent encourages traditional consumptive uses of water and impedes non-consumptive uses. Throughout Colorado's history, the water law system has evolved to include new codified uses of water. This paper analyzes the behavior of stakeholder groups that drove legislative changes in the Colorado General Assembly in the most recent example of this evolution-the inclusion of non-consumptive recreational in-channel water rights as a codified use of water. Using a qualitative case study research method, this study finds that collaboration among formerly disenfranchised stakeholders explains their legislative success despite the lesser degree of influence these groups have over water rights in Colorado. (C) 2008 Western Social Science Association. Published by Elsevier Inc. All rights reserved.
\end{abstract}

Groups of policy actors influence the policy process significantly and can take the form of interrelated actors in policy communities (Kingdon, 2003), or coalitions of stakeholders within and outside government (Sabatier \& Jenkins-Smith, 1993). These groups use internal coordinated action to promote their preferred versions of policy change. This paper analyzes the role that groups played in the process of policy change in the case of recreational water rights policy in the Colorado legislature. This study asks whether stakeholder groups influence policy change and if so, what strategies they used to do so.

\section{Background: the recreational in-channel diversion water right}

The Western United States is unlike the rest of the country primarily due to the variability of water supply and aridity of the environment (Neel, 1994; Worster, 1987). In these dry western states, water is the source of continual political conflict (Worster, 1987). While

* Tel.: +1 3034920364 .

E-mail address: deserai.crow@colorado.edu. 
water law in the arid West is similar in many of its foundational principles, specifically the use seniority to determine allocation of water, Colorado's system is the purest form of prior appropriation.

Prior appropriation doctrine dictates that users who divert and put water to a beneficial use first have priority in use of that water (Getches, 1997; Worster, 1985). Most water in the West is controlled under this priority system by agricultural interests and increasingly by municipalities, through municipal purchases of agricultural water rights to supply booming populations. A potential appropriator must meet several legal requirements to be granted a water right (Getches, 1997), which is done in Colorado through adjudication. This includes putting the water to a beneficial use. The Colorado Constitution does not define beneficial use (Hobbs, 1997), but it is statutorily defined as the "use of that amount of water that is reasonable and appropriate under reasonably efficient practices to accomplish without waste the purpose for which the appropriation is lawfully made" (Colorado Revised Statutes, sec. 37-92-103 [4]).

Most significantly, the user was required historically to take the water from the stream through a diversion and, therefore, prior appropriation was not compatible with instream or non-consumptive uses of water. This requirement for diversion was eliminated in Colorado in 1973, but the requirement of control of water still exists, preventing instream flow water rights being held by private entities (Hobbs, 2007). This means that water cannot flow naturally in its course without some type of control mechanism such as a dam or other man-made structure.

Those uses classified as beneficial have evolved from irrigation, domestic, and mining to include uses such as instream flows to protect species and their habitat and to provide recreational experiences. The newest of these is the inclusion of the recreational in-channel water right as a codified beneficial use in Colorado. This recreational water right is allowed solely for non-motorized boating and is primarily used to support kayak courses. These recreational water rights do not affect other water rights already in place because they are junior in priority. They can have consequences for future development of water resources upstream of the instream right, however. Once any water right is decreed, future upstream development or storage of water must ensure that the downstream rights are fulfilled before any new diversions can take place. In this way, instream water rights can alter future water development despite being non-consumptive.

In the last two decades of the 20th Century, there was tremendous growth in Colorado and elsewhere, of recreational boating on rivers, particularly the sports of whitewater rafting and kayaking. Beginning in 1998, 12 Colorado communities applied for and 10 have been granted ( 2 cases are pending) a new recreational water right, the recreational in-channel diversion (RICD), which allows communities to keep a specified amount of water in the stream channel for recreational boating. This water right is a key departure from traditional consumption-based water rights in western states and marked a significant shift in water policy in Colorado. While still named a diversion in keeping with the traditional water rights system, the control of water under the RICD consists of placing engineered structures in the channel to create riffles, waves, and obstacles for boaters to enjoy. Generally, these structures are designed to blend into the natural surroundings and can, at times, provide improved habitat for aquatic life. The policy process of RICD water rights becoming a statutorily defined use of water in Colorado is the focus of this research that examines the legislative strategy of stakeholders. 


\section{Literature: stakeholder influence}

In advocating for the development of a more comprehensive theory of the policy process, Sabatier (1991) argued that any theory of policy change must include a focus on policy communities, networks, and subsystems which include actors from within and outside government. Definitions of groups active in the policy process are often limited to those groups that fit into the traditional interest group model. These groups are also defined as voluntary organizations outside of the political system that engage in behavior designed to influence government policy or action (Andrews \& Edwards, 2004), which leaves other non-interest group actors within and outside government assigned to other categories.

While this research study does not employ a formal advocacy coalition framework model, the definition of advocacy coalitions presents a superior definition for the purposes of this study. Advocacy coalitions are groups "composed of people from various organizations who share a set of normative and causal beliefs and who often act in concert" (Sabatier, 1988, p. 133). These coalitions are comprised of actors from within and outside of government including elected officials, agencies, interest groups, journalists, and issue experts. These multiple actors are vital to understanding the complex process of policy change. These groups "compete over whose policy objectives are translated into governmental policy" (Weible \& Sabatier, 2005, p. 181). An accurate view of policymaking involves not only the traditional actors included in the iron triangle model, but also the policy subsystems at work in government and the multiple actors involved in these subsystems (Sabatier, 1988; Weible \& Sabatier, 2005).

The advantages of using this definition of advocacy groups are related to its ability to simplify "the hundreds of actors involved in policy change" and aggregate them "into a manageable number of belief-based coalitions" (Sabatier \& Jenkins-Smith, 1993, p. 212). The actors within advocacy groups share core beliefs related to policy issues (Sabatier, 1988). Policy change results from a competition among advocacy coalitions as well as an exchange of ideas over a period of time that leads to learning among coalitions.

Research has focused on the stages in the policy process where groups can have the most influence over policy outcomes. Coalitions of policy interests are thought to influence the agenda setting phase of policymaking where they can "bring greater attention, raise awareness, and create urgency around claims" (Andrews \& Edwards, 2004, p. 493). Other research describes policy change as "the result of multiple interactions among groups seeking to propose new understandings of issues" (Baumgartner \& Jones, 1993, p. 237). Studies on the influence of actors such as interest groups, media, elected officials, agencies, and experts indicate that these actors exert an non-trivial degree of influence over policy outcomes, policy agendas, and policy decision making (Baumgartner \& Jones, 1993; Kingdon, 2003; Sabatier \& Jenkins-Smith, 1993).

Group influence in this process is generally focused on lobbying legislators to (1) increase the size of their supportive coalitions in the legislature, (2) shape the content of legislation (Hojnacki \& Kimball, 1998), and (3) focus public or government attention on issues of importance to these groups (Baumgartner \& Jones, 1993; Kingdon, 2003). While coalitions of policy actors can have the strongest influence over agenda setting, they are also important to policy selection and are often involved in committee hearings. Stakeholder groups are able to influence legislative outcomes during the committee hearing stage of legislation because this process 
allows testimony from various groups and individuals regarding legislation, and groups can also effectively alter the details and language of legislation at this stage (Austen-Smith, 1993; Hall \& Wayman, 1990). Because stakeholders cannot influence legislation on the floor of the legislature as they can in committee, this is the primary venue for formal stakeholder involvement.

What strategies, then, do stakeholders use to influence the legislative process in these committee settings while legislation is pending with regard to environmental policymaking? If, as Long and Arnold (1995) argue, environmental groups are taking increasingly adversarial stances in relation to governmental policy makers due to what they believe is a history of poor policy performance, then the answer to the question might involve forming adversarial relationships. If, on the other hand, collaborative mechanisms for environmental policy are effective, then perhaps the picture is one of collaboration among competing interests (Poncelet, 2001). A combination of these forces also may drive policy change, where outcomes are not only determined by "the relative success of opposing forces" but also by whether "those forces can agree to support policies designed to produce mutual gains" (Quirk, 1989, p. 905).

Policy success is also often found among long-standing groups of stakeholders (Putnam, 1993). These groups can promote public policy success by helping to solve the collective action problems that are endemic in our political process (John, 2005). These networks of policy actors, however, are not guaranteed success simply due to their networks of communication and influence. Punctuated equilibrium theory demonstrates that disenfranchised stakeholders can help redefine policy issues, which promotes policy change (Baumgartner \& Jones, 1993, p. 9).

Based upon this literature presented above, it is clear that stakeholder groups are important units of analysis in attempting to understand policy change. It is also clear that the committee hearing phase of legislation is a useful process to analyze in attempting to understand the role of stakeholders and the tactics they use to influence legislation. In this analysis, it is important to examine the role of coalitions of actors as well as long-standing networks of actors.

\section{Methods}

A qualitative case study research method was used in this study to investigate the process with regard to RICD legislation and stakeholder group behavior. A case study "investigates a contemporary phenomenon within its real-life context, especially when the boundaries between phenomenon and context are not clearly evident" (Yin, 2003, pp. 13). Because this study attempts to understand complex social processes, case study method is appropriate.

Three sources of data were utilized for this study. First, legal and legislative data were analyzed to construct the broad case study narrative that is provided as background for this study. Second, in-depth interviews were conducted with water experts in Colorado who were identified through snowball sampling and documentation from legislative hearings as taking part in the legislative process. The groups subjects are affiliated with are listed in Appendix A. Seventy-five interviews inform the discussion of stakeholder policy interests. Twenty-seven interviews with subjects involved in and familiar with the legislative process with regard to recreational water rights inform the analysis of stakeholder behavior in the Colorado General 
Assembly. Of the interview subjects surveyed with regard to legislation, 12 were affiliated with RICD supporter groups, 11 were opponents, and 4 did not side with either position. Finally, testimony from the Senate Committee on Agriculture, Natural Resources, and Energy, and the House Committee on Agriculture, Livestock, and Natural Resources (and in one case the Senate Committee on Public Policy and Planning) were coded for stakeholder involvement and testimony given with regard to Colorado Senate Bills 216 (2001), 62 (2005), and 37 (2006).

All interviews were coded for mentions of stakeholder participation in legislative action using QSR's NVivo software. Additionally, these interviews were coded and analyzed for descriptions of stakeholder views, policy opinions, and characterizations of stakeholders. Codes were created for organizing raw data according to conceptual elements from literature presented above. From the interview data, however, these categories were expanded. In this manner, literature helped to form many of the basic codes used in this analysis but the data led to the creation of more specific codes upon which to base the data analysis.

The coded data collected for this study were analyzed using a grounded theory approach. Strauss and Corbin (1998) describe grounded theory as a system of conceptual ordering, "organization of data into discrete categories according to their properties and dimensions and then using description to elucidate those categories" (p. 19). This ordering is done, not through a quantification of qualitative data, but a "nonmathematical process of interpretation, carried out for the purpose of discovering concepts and relationships in the raw data" (p. 11). By breaking data down into component parts, it is possible to construct a thorough understanding of the important elements in a complex process involving multiple actors and influences. These data collection and analysis procedures allow for an understanding of the roles that stakeholders played in the formation of recreational water rights policy in Colorado.

\subsection{The recreational in-channel diversion story}

A state formerly dependent on agriculture, mining, and other traditional economic drivers, Colorado's economy has changed considerably in the past several decades. Tourism is the second largest industry in Colorado and much of that tourism is recreation oriented (Colorado Office of Economic Development, 2005). Water sports are a large part of Colorado's economy, with the rafting industry bringing " $\$ 135$ million during the 2005 season, making it Colorado's number one summer tourism industry" (Colorado River Outfitters Association, 2006). Kayaking has also become a popular recreational activity for tourists and residents.

In 1998, the city of Golden, Colorado applied for a water right to maintain flows in its newly built kayak course. Based on previous legal precedent, Golden's water rights application was granted by the water court (City of Golden Application for Surface Water Rights [1998]). Golden was followed by two other Colorado communities, Vail and Breckenridge, which applied for recreational in-channel water rights for their kayak courses in 2000 and were granted those rights (Eagle River Water and Sanitation District Application for Water Rights [2002]; Town of Breckenridge Application for Water Rights [2002]). These three cases were appealed to the Colorado Supreme Court by the State of Colorado. In State Engineer v. City of Golden (Colo. 2003 ) and State Engineer v. Eagle River Water and Sanitation District and State Engineer v. Town of Breckenridge (Colo. 2003), the lower water court decisions were affirmed. State water resource agencies aggressively litigated each of these early recreational water rights cases. 
These agencies represented the State's concerns that these rights would limit future water development.

\subsection{Opponents and supporters of recreational in-channel water rights}

Advocacy coalition framework calls for a specific explication of belief-based coalitions. The following descriptions of RICD supporter and opponent coalitions are based upon interview data with Colorado water experts. Interview subjects were asked to describe the views of their own interest group, if applicable, as well as others who share the same opinion. Subjects were also asked to describe the viewpoints of opponent groups on the issue of RICD water rights.

Opponents of this new water right primarily included water suppliers, agricultural interests, and the State of Colorado. Water suppliers develop and provide water for purposes of domestic and agricultural use. Most of these entities hold senior water rights, but feared that this new recreational water right would place restrictions on what water development and storage could take place in the future. Agricultural interests were also opposed to the recreational water right. Their concerns had little to do with present use of water, since they generally hold the most senior water rights in Colorado. As agriculture becomes less profitable in Colorado, many farmers and ranchers sell their water rights to municipalities for high prices. Some agricultural water users feared that recreational water rights would diminish flexibility in water use and prevent these types of sales. Other agricultural interests feared that by limiting flexibility of municipalities to get water from other sources, recreational water rights would encourage municipalities to purchase agricultural water rights and hasten the decline of agriculture in Colorado. The third opponent of recreational water rights, and the entity that fought them most aggressively, was the State of Colorado. The large amounts of water being requested in these cases led state agencies to pursue litigation aggressively. The State of Colorado was also politically opposed to the basic idea of this new water right, according to interview subjects.

Supporters of the recreational water right included environmental groups, recreation groups, and communities whose economies are recreation-based. Environmental groups supported this water right because it maintains flows in rivers that are increasingly depleted. Although Colorado allows instream flows to protect habitat and species, these water rights are for minimal flows to support aquatic life and are therefore ineffective according to environmental advocates. Recreation groups supported the water right because it not only promotes their personal enjoyment of the river, but it also protects flows from depletion in the future and thus protects the future of recreational industries. Communities that have applied for, or plan to apply for, an RICD also supported the new water right and legislation that protects it. These communities saw it as a benefit to their local economies to maintain stream flows and build river recreation opportunities. Several of these communities also saw it as a means to protect flows in the river for environmental purposes.

There is a history of collaboration among the opponents of RICD water rights. This has included legislative lobbying efforts. For example, many municipalities, water suppliers, and agricultural interests are members of the Colorado Water Congress, a statewide lobbying organization. There is not, however, a well-established history of collaboration among the recreation and environmental communities in water rights matters. In some cases, these groups have been at odds in the past, specifically related to recreational impacts on the environment. 


\section{Results: stakeholder involvement in legislative policy change}

In Colorado's General Assembly, three attempts at legislation were proposed in response to growing concerns among traditional water users and state agencies related to the initial attempts to obtain recreational in-channel water rights by Colorado communities. During these three legislative processes, advocacy groups played an integral role in legislative debate as well as lobbying. This section analyzes what role these groups played in the Colorado General Assembly's attempts to define and restrict the recreational in-channel water right.

Attempting to understand the influence that stakeholders had in the legislative process requires an understanding of the information legislators used in making their decision to accept or reject proposed legislation, which requires an examination of the witness testimony before legislative committees. These committees are the primary place where discussion between legislators and stakeholders takes place, at least in a formal setting. However, as the house sponsor of Senate Bill 37 stated, "the role of the lobbyists was absolutely critical for resolution of this situation... because it's whoever has a presence in the building is the person that's going to be there if you want to get. . . people together and talk about. . . a bill." It is, therefore, clear that discussion over legislation also takes place outside of the formal committee hearing setting.

The analysis of committee testimony suggests that an evolution took place in stakeholder strategy with regard to legislation in the case of the RICD. This evolution primarily involved the recreational and environmental groups that support RICD water rights. In 2001, legislation was first introduced in the legislature to define, codify, and limit recreational water rights. This legislation, Senate Bill 216, resulted when state water agencies urged legislative intervention in reaction to court rulings affirming recreational water rights. In 2001, RICD water rights had not been talked about extensively outside of water law and policy circles. RICD proponents were not prepared for this first legislative battle, largely because it was initiated quickly and proponents of RICDs were simultaneously involved in three legal battles. By the time Senate Bill 62 was introduced in 2005, attempting to cap and dismantle recreational water rights, RICDs were well known in water policy circles, with seven communities filing RICD applications between 2001 and 2005. Senate Bill 62 met with greater opposition and was defeated in the House. When Senate Bill 37 was introduced in 2006, further attempting to define and shape recreational water rights, both opponents and supporters were entrenched. Despite the fact that recreational and environmental interests are generally not able to influence water rights policy to the degree that traditional water users can, they were able influence legislative debates over recreational in-channel water rights. This study seeks to understand how they accomplished such a feat.

The table below illustrates participation by stakeholders who supported and opposed RICD water rights and the legislative results. Opponents of RICD rights constituted $60 \%$ of committee hearing testimony given in 2001, while they only comprised 32\% in 2005, and $42 \%$ in 2006. The information that stands out in these data is the increase in participation among supporters of RICDs after the passage of Senate Bill 216 in 2001 Table 1.

In subsequent legislation, these pro-RICD groups were heavily involved in the debate. At the same time, there was a decline in absolute levels of participation among stakeholders that opposed the RICD water right. Despite being less influential in water policy, the recreational and environmental interests effectively opposed legislation that would significantly restrict RICDs. The next important question to answer is what the nature of this participation was. 
Table 1

Legislative participation and legislative outcomes.

\begin{tabular}{llll}
\hline Legislation & $\begin{array}{l}\text { Number of testimonials provided } \\
\text { (\% of total testimony) }\end{array}$ & $\begin{array}{l}\text { Number of distinct interest } \\
\text { groups represented }\end{array}$ & $\begin{array}{l}\text { Legislative } \\
\text { outcome }\end{array}$ \\
\hline $\begin{array}{c}\text { Senate Bill 216 (2001) } \\
\text { RICD supporters }\end{array}$ & $14(40 \%)$ & 13 & $\begin{array}{l}\text { Lost } \\
\text { Won }\end{array}$ \\
RICD opponents & $21(60 \%)$ & 15 & Won \\
Senate Bill 62 (2005) & & & Lost \\
RICD supporters & $32(68 \%)$ & 29 & No clear victory \\
RICD opponents & $15(32 \%)$ & 12 & No clear victory \\
Senate Bill 37 (2006) & & & 14 \\
$\quad$ RICD supporters & $18(58 \%)$ & 9 & \\
RICD opponents & $13(42 \%)$ & & \\
\hline
\end{tabular}

Evidence from interviews answers this question and helps develop an understanding of why stakeholders who had once been relatively disenfranchised with regard to water policy debates gained legislative victories in 2005 and 2006. Data from the interviews are summarized in Table 2. When asked what groups or individuals were involved in legislation, interview subjects mentioned supporter groups and opposition groups in similar aggregate numbers, suggesting that there was not a difference in perceived stakeholder participation. The supporter groups, however, were a more cohesive list of participant groups. All mentions of RICD supporters fell into four categories: recreational groups, environmental groups, RICD communities, and the law firms that communities hired to litigate their water rights cases.

Table 2

RICD stakeholder participation in legislation.

\begin{tabular}{|c|c|c|}
\hline Stakeholder group name & $\begin{array}{l}\text { Number of mentions } \\
\text { (\% subtotal) }\end{array}$ & $\begin{array}{l}\text { Relevant information provided about } \\
\text { stakeholder by interview subjects }\end{array}$ \\
\hline \multicolumn{3}{|l|}{ Pro-RICD } \\
\hline Recreation interests & $10(14.9 \%)$ & $\begin{array}{l}\text { "A strong alliance between.... recreation and } \\
\text { environmental communities." }\end{array}$ \\
\hline Environmental interests & $27(40.1 \%)$ & $\begin{array}{l}\text { "The environmental communities have been } \\
\text { pretty supportive." }\end{array}$ \\
\hline Recreation communities & $12(17.8 \%)$ & $\begin{array}{l}\text { "The local interests... they want to make sure } \\
\text { if they want to have a kayak course they can." }\end{array}$ \\
\hline Law firms & $18(26.8 \%)$ & "A leader in that whole side of it." \\
\hline Total mentions & Subtotal 67 & $49 \%$ of total stakeholder mentions. \\
\hline \multicolumn{3}{|l|}{ Anti-RICD } \\
\hline State of Colorado & $10(14.3 \%)$ & "The state agencies kind of pushing back." \\
\hline Agricultural interests & $12(17.1 \%)$ & $\begin{array}{l}\text { "Agriculture has continued to be just almost } \\
\text { across the board opposed." }\end{array}$ \\
\hline Water providers/developers & $28(40 \%)$ & $\begin{array}{l}\text { "Water users pushing to have restrictions put } \\
\text { on recreational in-channel diversions." }\end{array}$ \\
\hline Individual legislators & $5(7.1 \%)$ & $\begin{array}{l}\text { "Major opposition was. . from the } \\
\text { legislators." }\end{array}$ \\
\hline Colorado water congress & $7(10 \%)$ & $\begin{array}{l}\text { "Colorado Water Congress played a critical } \\
\text { role." }\end{array}$ \\
\hline Other actors & $8(11.4 \%)$ & \\
\hline Total mentions & Subtotal 70 & $51 \%$ of total stakeholder mentions. \\
\hline
\end{tabular}


Interview data suggest that the number of groups opposed to RICD water rights outnumbered groups in support of the water right, but this majority did not translate into legislative success. It is important to analyze the strategies used by pro-RICD stakeholders to understand this success.

When asked to describe the legislative process and the effectiveness of groups that were involved, interview subjects consistently pointed to environmental interests as the most effective groups supporting RICD water rights. One subject said, "I think Trout Unlimited specifically has been to a lot of these court cases and the legislation, have been wonderful in terms of working together with the recreation groups." Another subject described the importance of environmental coalitions: "Colorado Environmental Coalition I would. . . give a huge gold star. . in trying to protect rivers for recreation, environmental reasons."

Interviews also indicate that a specific law firm was particularly effective in promoting RICDfriendly legislation. "The people that are probably the most effective in lobbying for RICDs is the Porzak law firm [the law firm that represented Golden, Vail, and Breckenridge]. . they've been very effective. . . in. . . legislation associated with RICDs." This does not, however, seem to have been driven simply by their role as hired water counsel. Interview subjects familiar with the law firm stated that their work was driven partially by personal interest. "[The primary partner] has strong environmental leanings." Attorneys within the law firm confirm these descriptions. "We [the law firm] have always been closely aligned and tied in with the recreation-based economy." They describe their legal and legislative success as being driven at least partially by their personal stake in the issue: "You had to be very passionate. You had to exude that passion, otherwise I don't think we would have won [quote from firm attorney]."

Many interview subjects further described the environmental groups as "working together" with the recreational community, developing "a broad coalition" in support of recreational water rights, and "partnering with towns and cities" that had an interest in applying for RICDs. One of the most significant pieces of information provided by interview subjects is that the pro-RICD groups were often referred to as a coalition, caucus, or lobbying group. RICD opponents were not described in this manner. This evidence suggests that there was a coordinated campaign by pro-RICD stakeholders to influence the legislative process. Cooperative language was used four times as frequently to describe the stakeholders who supported recreational water rights in comparison to those groups that were opposed to RICDs Table 3.

The pro-RICD campaign was described by one subject as "a great cooperative effort, especially statewide." Another stated that "the coalition that was formed for Senate Bill 62

Table 3

Language used to describe stakeholder groups.

\begin{tabular}{lcl}
\hline Cooperative terminology & Pro-RICD stakeholders & Anti-RICD stakeholders \\
\hline Community & 9 & 5 \\
Coalition & 5 & 0 \\
Caucus & 1 & 0 \\
Conglomerate & 1 & 0 \\
Alliance & 1 & 0 \\
Cooperative & 1 & 0 \\
Working Together & 1 & 0 \\
Coordinated & 1 & 0 \\
Total & 20 & 5 \\
\hline
\end{tabular}


regrouped for Senate Bill 37. . really advocating for the best policy possible.” These formerly marginalized stakeholders gained greater influence over RICD legislation through this collaboration among stakeholders, forming belief-based coalitions consistent with advocacy coalition framework.

The only group opposed to recreational water rights that was described as being effective in lobbying was the Colorado Water Congress, a policy and lobbying group that is comprised of traditional water users such as irrigators and water providers. "There's a statewide organization called the Colorado Water Congress that. . . is probably the preeminent statewide organization in terms of lobbying." This was also the only anti-RICD group that was described as being a "statewide organization" of traditional water users. This lack of coordination and cooperation on the part of traditional water user groups appears to account for their relative lack of success despite the greater influence they generally have over water rights legislation.

\section{Discussion and conclusion}

An evolution in participation occurred through the three phases of legislation, primarily among stakeholders supportive of RICDs. Collaboration was ongoing throughout the legislative process among pro-RICD stakeholders, consistent with the advocacy coalition framework model of coordination within coalitions. At the same time, all interview subjects indicated that there was no cooperation among competing policy interests. Internal collaboration among belief-based coalitions of actors, as well as external competition between policy opponents drove the RICD legislative process forward. Stakeholders opposed to RICDs outnumbered those who support the water right and have more established networks of influence, but because supporters developed a collaborative lobbying strategy, the policy outcome favored RICD supporters.

While traditional water users still influence water policy decisions in Colorado to a much greater extent than non-traditional users, these non-traditional groups have developed legitimacy, coordinated campaigning strategies, and collaborative tactics that allowed them to wield influence over legislation with regard to water rights for non-traditional uses. These findings support arguments regarding advocacy coalition behavior and the belief-based coalitions that form around policy issues. Rather than simply interest group presence driving policy change, it was the presence of coalitions of actors across interest groups that effectively promoted policy change. Additionally, the finding regarding the ineffectiveness of long-standing stakeholder networks supports findings from punctuated equilibrium theory in which disenfranchised actors are able to increase their legitimacy and policy influence (Baumgartner \& Jones, 1993). Punctuated Equilibrium Theory argues that this is done through policy redefinition and venue shopping, but this study shows that it can also be done through collaborative campaigning.

This research provides insight into stakeholder behavior, consistent with previous research, and indicates that collaboration among stakeholders leads to more effective legislative lobbying efforts. This research provides insights based upon a case that is a difficult policy issue for disenfranchised stakeholders to gain influence. This study argues that a collaborative pattern of stakeholder behavior resulted in legislative success among non-traditional water user groups, which may mean that collaboration is an important tool for disenfranchised stakeholders in 
other policy venues. This, therefore, provides opportunity for future research into the success of formerly disenfranchised groups based upon patterns of stakeholder collaboration.

In order to expand this research, additional studies should be conducted in a variety of state-level policy settings to compare these results to policy areas other than water rights and states beyond Colorado. In addition, as mentioned above, there is also an informal level of legislative lobbying and negotiation that is important to the process of policy change that this study cannot capture. Research into these informal processes is essential to understanding the entire picture of stakeholder behavior and influence in policy change.

\section{Acknowledgements}

The author thanks Deborah Rigling Gallagher, the Editor of the Social Science Journal, and one anonymous reviewer for their assistance in reviewing several drafts of this paper and for their insightful comments. Thank you also to the many community members and water experts across Colorado who served as interview subjects for this study.

An early version of this paper was presented at the American Society for Public Administration's Annual Meeting, March 23-27, 2007 in Washington, DC.

\section{Appendix A}

State of Colorado

Colorado Department of Agriculture

Colorado General Assembly

Colorado Department of Natural Resources

Colorado Division of Water Resources

Colorado Office of the Attorney

General

Colorado Division of Wildlife

Colorado Supreme Court

Colorado Water Conservation Board

Recreation and Environmental Groups

Colorado Environmental Coalition

The Nature Conservancy

Colorado River Outfitters Association

Trout Unlimited

Colorado White Water Association

Western Resource Advocates

Water Suppliers (conservancy districts unless otherwise noted)

Colorado River Water Conservation District

Upper Arkansas River

Denver Water Board

Upper Gunnison River

Northern Colorado

Upper Yampa River

Other

Colorado Water Congress

Within each RICD community, water attorneys, local government personnel, elected officials, and local citizen supporters and opponents were also interviewed 


\section{References}

Andrews, K., \& Edwards, B. (2004). Advocacy organizations in the U.S. political process. Annual Review of Sociology, 30, 479-506.

Austen-Smith, D. (1993). Information and influence: Lobbying for agendas and votes. American Journal of Political Science, 37(3), 799-833.

Baumgartner, F. R., \& Jones, B. D. (1993). Agendas and instability in American politics. Chicago: University of Chicago Press.

City of Golden Application for Surface Water Rights. (1998). No. 98CW448 (Water Division 1, December 10, 1998).

Colorado Office of Economic Development. (2005). Colorado Data Book. Retrieved June 5, 2007, from http://www. state.co.us/OED/business-development/colorado-data-book.cfm.

Colorado River Outfitters Association. (2006). Commercial River Use in Colorado: 2006 Year End Report. Retrieved September 10, 2007, from http://www.croa.org/pdf/2006_Commercial_Rafting_Use_Report.pdf.

Definitions of Colorado Water Law, Colorado Revised Statutes. (2007). sec. 37-92-103.

Eagle River Water and Sanitation District Application for Water Rights. (2002). No. 00CW259 (Water Division 5, June 5, 2002).

Getches, D. H. (1997). Water law: In a nutshell. St. Paul, MN: West Publishing.

Hall, R. L., \& Wayman, F. W. (1990). Buying time: Moneyed interests and the mobilization of bias in congressional committees. The American Political Science Review, 84(3), 797-820.

Hobbs, G. J. (1997). Colorado water law: An historical overview. University of Denver Water Law Review, 1(1), $1-138$.

Hobbs, G. J. (2007 (February 15)). Colorado and western water law. The Water Report, 1-15.

Hojnacki, M., \& Kimball, D. C. (1998). Organized interests and the decision of whom to Lobby in congress. The American Political Science Review, 92(4), 775-790.

John, P. (2005). The contribution of volunteering, trust, and networks to educational performance. Policy Studies Journal, 33(4), 635-656.

Kingdon, J. W. (2003). Agendas alternatives and public policies (2nd ed.). New York: Longman.

Long, F. J., \& Arnold, M. B. (1995). The power of environmental partnerships. Fort Worth, TX: Harcourt Brace \& Company.

Neel, S. R. (1994). A place of extremes: Nature, history, and the American west. The Western Historical Quarterly, 25(4), 488-505.

Poncelet, E. C. (2001). Personal transformation in multistakeholder environmental partnerships. Policy Sciences, 34(3-4), 273-301.

Putnam, R. D. (1993). Making democracy work. Princeton, NJ: Princeton University Press.

Quirk, P. J. (1989). The cooperative resolution of policy conflict. The American Political Science Review, 83(3), 905-921.

Sabatier, P. A. (1988). An advocacy coalition framework of policy change and the role of policy-oriented learning therein. Policy Sciences, 21(2-3), 129-168.

Sabatier, P. A. (1991). Toward better theories of the policy process. PS: Political Science and Politics, 24(2), 147-156.

Sabatier, P. A., \& Jenkins-Smith, H. (1993). The advocacy coalition framework: Assessments, revisions, and implications for scholars and practitioners. In P. A. Sabatier \& H. Jenkins-Smith (Eds.), Policy change and learning: An advocacy coalition approach. Boulder, CO: Westview Press.

Senate Bill 216. (2001). Colorado General Assembly.

Senate Bill 37. (2006). Colorado General Assembly.

Senate Bill 62. (2005). Colorado General Assembly.

State Engineer v. City of Golden. (2003). 69 P.3d. 1027 (Colo. 2003).

State Engineer v. Eagle River Water and Sanitation District and State Engineer v. Town of Breckenridge. (2003). 69 P.3d. 1028 (Colo. 2003). 
Strauss, A., \& Corbin, J. (1998). Basics of qualitative research: Techniques and procedures for developing grounded theory. Thousand Oaks, CA: Sage Publications.

Town of Breckenridge Application for Water Rights. (2002). No. 00CW281 (Water Division 5, June 5, 2002).

Weible, C. M., \& Sabatier, P. A. (2005). Comparing policy networks: Marine protected areas in California. Policy Studies Journal, 33(2), 181-199.

Worster, D. (1985). Rivers of empire: Water, aridity, and the growth of the American west. New York: Oxford University Press.

Worster, D. (1987). New west true west: Interpreting the region's history. The Western Historical Quarterly, 18(2), $141-156$.

Yin, R. K. (2003). Case study research: Design and methods. Thousand Oaks, CA: Sage Publications. 